
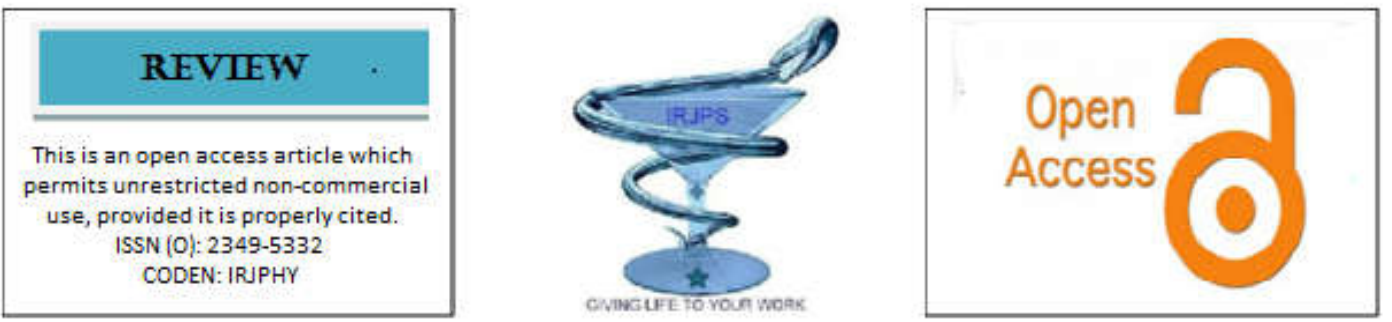

\title{
A REVIEW ON RECENT ADVANCEMENT IN HYPHENATED TECHNIQUES FOR THE ANALYSIS OF SECONDARY METABOLITES
}

\author{
Nikhil K. Gabhale*, Amit S. Tapkir
}

P. E. Society's, Modern College of Pharmacy, Yamunanagar, Nigdi, Pune, Maharashtra, India

\begin{abstract}
:
This study includes study of hyphenated techniques combine chromatographic and spectral methods to exploit the advantage of both. Chromatography produces pure or nearly pure fractions of chemical parts in an exceedingly mixture. The development of the prescription drugs brought a revolution in human health. The review combined technique includes numerous techniques that are used today for analysis. Chromatographic techniques Gas Chromatography, LC etc., are used for separation and spectroscopic techniques like NMR, MS, IR used for identification purpose. Pharmaceutical substances can develop impurities at the time of their development, transportation and storage that makes the pharmaceutical risky to be administered so they have to be detected and quantitated. For this analytical instrumentation and methods play an important role. This review highlights the role of the analytical instrumentation and the analytical methods in assessing and identification of glycosides, alkaloids, tannins and resins from herbal plants. The review highlights a variety of hyphenated analytical techniques applied in the analysis of secondary metabolites from plants.
\end{abstract}

KEYWORDS: Hyphenated techniques, Glycosides, Alkaloids, Tannins \& Resins.

Corresponding Author: Nikhil K. Gabhale Indian Research Journal of Pharmacy and Science; 25(2020)2164-2176; 


\section{INTRODUCTION:}

The term "hyphenation" was first adapted by Hirsch Feld in 1980 to describe a possible combination of two or more instrumental analytical methods in a single run (Hirschfeld, 1980). The aim of the coupling is to obtain an information-rich detection for both identification and quantification compared to that with a single analytical technique [1].

The hyphenated technique is the combination or the coupling of the different analytical techniques ${ }^{[2]}$. Mainly chromatographic techniques are combined with spectroscopic techniques. Then the separated parts of the mixture from action technique can enter into the qualitative analysis technique through an interphase. For examples, in GC-MS the separated components from gas chromatography enter to MS which is followed by ionization, mass analysis, and detection of mass-to-charge ratios of ions generated from each analyse by the mass spectrometer. Jet/orifice extractor, effusion separator, and membrane separator can be used to connect GC with MS. In LC- Nuclear Magnetic Resonance coupling the analytical flow cell was at the start made for continuous-flow to Nuclear Magnetic Resonance. Use of LC-MS-MS is increasing speedily day by day. Hyphenated techniques like HPLC coupled to ultraviolet and mass spectroscopy (LC-UV-MS) are extraordinarily helpful together with biological screening for a speedy survey of natural product. Nowadays, varied forms of LC-MS systems incorporating differing types of interfaces are obtainable commercially. The term hyphenated techniques refer to separation, identification, and the hyphenated techniques show better analysis of the samples are components specificity, accuracy, precision ${ }^{[1]}$. The term combined techniques vary from the mixture of separation -separation, separation-identification\& identificationidentification techniques ${ }^{[3]}$.

\subsection{Advantages}

a. For fast and accurate analysis

b. A Higher degree of automation.

c. Higher sample throughput.

d. Better reproducibility.

e. Reduction of contamination due to its closed system.

f. Separation of quantification at the same time.
1.2 Types of hyphenated techniques

1.2.1. Double hyphenated techniques.

1.2.2. Triple hyphenated techniques.

\subsubsection{Double hyphenated techniques}

- LC-MS

- LC-NMR

- LC-IR

- CE-MS

- GC-IR

- GC-MS

- HPLC-DAD

- GC-FTIR

\subsubsection{Triple hyphenated techniques}

- LC-API-MS

- $\quad$ APCI-MS-MS

- $\quad$ ESI-MS-MS

- LVI-GC-MS

- LC-ESI-MS

- LC-UV-NMR-MS-ESI

- LC-NMR-MS

- LC-DAD-API-MS

- LC-PDA-MS

- LC-PDA-NMR-MS

- $\quad$ SPE-LC-MS ${ }^{[1]}$

\subsection{GC-MS}

GC-MS, that could be a combined technique developed from the coupling of Gas Chromatography and MS. Mass spectra obtained by this combined technique supply additional structural info supported the interpretation of fragmentation. The fragment ions with totally different relative abundances may be compared with library spectra. Compounds that square measure adequately volatile, small, and stable in high temperature in $\mathrm{GC}$ conditions can be easily analyzed by GC-MS. In GCMS a sample is injected into the port of GC device vaporized, separated in the GC column, analyzed by MS detector and recorded.

\subsection{LC-IR}

The hyphenated technique developed from the coupling of an LC and the detection method infrared spectroscopy (IR) or (FTIR) is known as LC-IR or HPLC-IR. A helpful chemical analysis technique for the identification of chemical compound, because in the mid-IR region the structures of organic compounds have many absorption band that are characteristic of particular functionalities eg.-OH, - $\mathrm{COOH}$. 


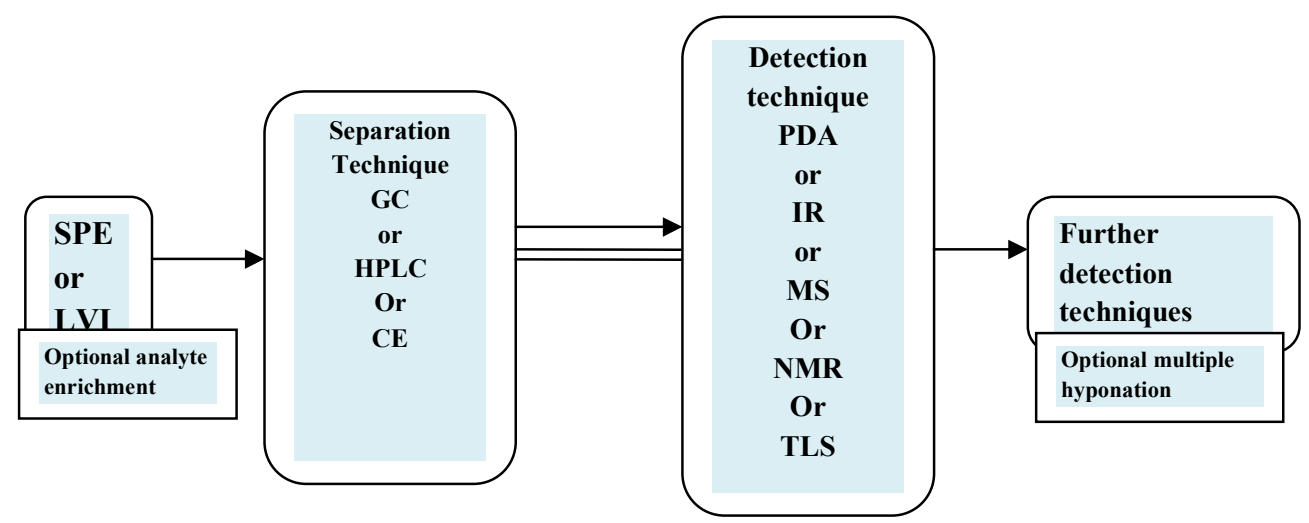

Fig 1. Schematic presentation of Double Hyponation of chromatographic and spectrometric techniques

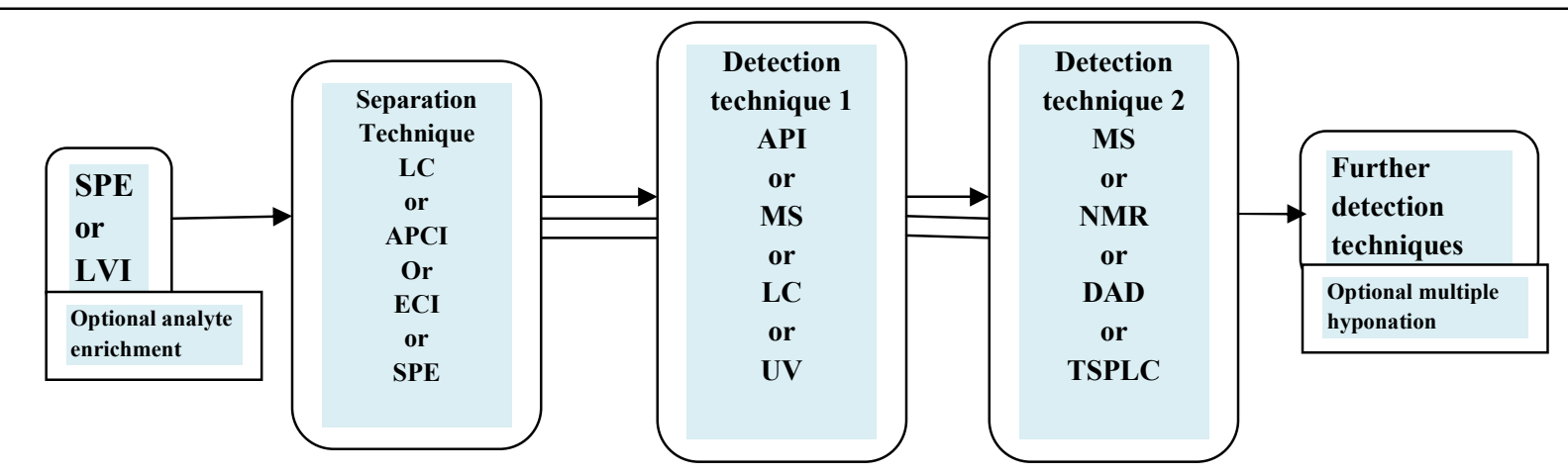

Fig 2. Schematic presentation of Triple Hyponation of chromatographic and spectrometric techniques

\subsection{LC-MS}

LC-MS or HPLC-MS refers to the coupling of an LC with a mass spectral data. The separated sample rising from the column may be known on the idea of its mass spectral information. An LC-Ms combines the chemical separating power of LC with the flexibility of associate degree MS to by selection sight and ensure molecular identity.

\subsection{CE-MS}

MS detector linked to a CE system for acquiring on-line MS data of the separated compound, the resulting combination is termed as CE-MS. CE analysis is driven by an electrical filed, performed in narrow tubes, and can result in the rapid separation of many hundreds of different compounds .Separation is achieved through channels inscibed on the surface of the capillary connected to associate degree external high voltage power provide that delivers sample to ESIMS. 


\subsection{LC-NMR}

Technological developments have allowed the direct parallel coupling of HPLC system to Nuclear Magnetic Resonance. The main prerequisites for on-line LC-NMR, in addition to the continuousflow probe for recording either continuousflow or stopped flow NMR spectra. For the high sensitivity, new RF system for multiple solvent suppression and improved dynamic vary gradient eluding capability and automatic peak piking/storing capability.

\section{PHYTOCONSTITUENTS}

\subsection{Glycosides:}

Table: 1 Hyphenated techniques for Glycosides

\begin{tabular}{|c|c|c|c|c|c|}
\hline $\begin{array}{l}\text { Sl. } \\
\text { No }\end{array}$ & $\begin{array}{l}\text { Name of } \\
\text { Plant }\end{array}$ & $\begin{array}{l}\text { Name of } \\
\text { active } \\
\text { constituent }\end{array}$ & $\begin{array}{c}\text { Hyphenated } \\
\text { technique } \\
\text { used }\end{array}$ & Significance & Reference \\
\hline 1. & $\begin{array}{l}\text { Quercus lea } \\
\text { flteas }\end{array}$ & $\begin{array}{l}\text { Flavonol } \\
\text { glycosides }\end{array}$ & $\begin{array}{l}\text { LC-DAD- } \\
\text { MS/MS }\end{array}$ & $\begin{array}{l}\text { Mexican Quercus species was developed } \\
\text { using different LC-DAD-MS/MS } \\
\text { methodologies \& hydrolyzable tannins and } \\
\text { flavonol glycosides, were identified and } \\
\text { quantified by RocíoGarcía-Villalba. }\end{array}$ & $\begin{array}{l}\text { [Rocio } \\
\text { Garcia- } \\
\text { Villalba etal } \\
2019]\end{array}$ \\
\hline 2. & $\begin{array}{l}\text { Digitalis } \\
\text { purpurea } \\
\text { (Foxglove) } \\
\text { plant }\end{array}$ & $\begin{array}{l}\text { Digitoxin } \\
\text { and digoxin } \\
\text {-cardiac } \\
\text { glycosides }\end{array}$ & $\mathrm{LC} / \mathrm{MS} / \mathrm{MS}$ & $\begin{array}{l}\text { Selective LC/MS/MS method used for the } \\
\text { determination of digoxin and digitoxin by } \\
\text { Xiaoning Lu, David S. Bell. }\end{array}$ & $\begin{array}{l}\text { [Xiaoning } \\
\text { Lu, David S. } \\
\text { Bell etal } \\
2010]\end{array}$ \\
\hline 3. & $\begin{array}{l}\text { B. } \\
\text { forficata } \\
\text { subsp. } \\
\text { pruinosa }\end{array}$ & $\begin{array}{l}\text { Quercetin } \\
\text { O-glycoside } \\
\text { derivatives }\end{array}$ & LC/ESI-MS & $\begin{array}{l}\text { The chemical composition analysed using } \\
\text { LC/ESI-MS for the presence of quercetin } \\
\text { and kaempferol glycosides by Lidiane da } \\
\text { Silveira Farias. }\end{array}$ & $\begin{array}{l}\text { [Lidiane da } \\
\text { Silveira } \\
\text { Farias etal } \\
2014]\end{array}$ \\
\hline 4. & $\begin{array}{l}\text { Cynodon } \\
\text { Dactylon }\end{array}$ & Glycosides & $\begin{array}{lr}\text { HPLC , LC- } \\
\text { MS, } \\
\text { NMR, } \\
\text { HTIR }\end{array}$ & $\begin{array}{l}\text { HPLC , LC-MS , H1-NMR, FTIR analysis } \\
\text { for the presence of Glycosides done by Zabin } \\
\text { k. bagewadi. }\end{array}$ & $\begin{array}{l}\text { [Zabin k. } \\
\text { bagewadi } \\
\text { etal 2014] }\end{array}$ \\
\hline 5. & $\begin{array}{l}\text { Pergulari } \\
\text { a } \\
\text { daemia } \\
\text { (Forssk) } \\
\text { Chiov }\end{array}$ & $\begin{array}{l}1,2- \\
\text { Benzenedica } \\
\text { rboxylic } \\
\text { acid, diethyl } \\
\text { ester (CAS) } \\
\text { Synaptogeni } \\
\text { n B }\end{array}$ & GC-MS & $\begin{array}{l}\text { Gas Chromatography - Mass Spectrum } \\
\text { (GCMS) analysis done for screening of } \\
\text { phytochemicals and to identify 1,2- } \\
\text { Benzenedicarboxylic acid, diethyl ester } \\
\text { (CAS) Synaptogenin B by Rukshana MS, } \\
\text { Doss A. }\end{array}$ & $\begin{array}{l}\text { [Rukshana } \\
\text { MS, Doss A } \\
\text { etal 2017] }\end{array}$ \\
\hline 6. & $\begin{array}{l}\text { leaves of } \\
\text { Sauropus } \\
\text { Androgyn } \\
\text { us }\end{array}$ & $\begin{array}{l}\text { Cardenolide } \\
\mathrm{S}\end{array}$ & GC-MS & $\begin{array}{l}\text { In the GC-MS analysis shows the presence } \\
\text { of Cardenolides bioactive compounds }\end{array}$ & $\begin{array}{l}\text { [Senthamarai } \\
\text { Selvi. V etal } \\
\text { 2012] }\end{array}$ \\
\hline 7. & Moringa & polyphenols & GC-MS & All the prepared extracts were also analyzed & [Mooza Al- \\
\hline
\end{tabular}




\begin{tabular}{|c|c|c|c|c|c|}
\hline & $\begin{array}{l}\text { peregrina } \\
\text { (Forssk.) } \\
\text { Fiori } \\
\text { leaves }\end{array}$ & $\begin{array}{l}\text { (tannins and } \\
\text { flavonoids), } \\
\text { steroids, } \\
\text { alkaloid, } \\
\text { carbohydrate } \\
\text { glycosides, } \\
\text { cardiac } \\
\text { glycosides, } \\
\text { and } \\
\text { terpenoids }\end{array}$ & & $\begin{array}{l}\text { by gas chromatography-mass } \\
\text { spectrometry to identify and characterize } \\
\text { glycosides, steroids, alkaloid, carbohydrate } \\
\text { by Mooza Al-Owaisi. }\end{array}$ & $\begin{array}{l}\text { Owaisi etal } \\
2014]\end{array}$ \\
\hline 8. & $\begin{array}{l}\text { Leaves Of } \\
\text { Albizia } \\
\text { Lebbeck } \\
\text { Benth }\end{array}$ & $\begin{array}{l}\text { Tri-O- } \\
\text { Glycoside } \\
\text { Flavonols } \\
\text { Kaempferol } \\
\text { And } \\
\text { Quercetin }\end{array}$ & FT-IR & $\begin{array}{l}\text { FTIR method was performed on a Thermo } \\
\text { Scientific Spectrophotometer system which } \\
\text { was used to detect Tri-O-Glycoside } \\
\text { Flavonols Kaempferol And Quercetin by } \\
\text { MD. Nazneen Bobby. }\end{array}$ & $\begin{array}{l}{[\mathrm{MD} .} \\
\text { NAZNEEN } \\
\text { BOBBY etal } \\
2012]\end{array}$ \\
\hline 9. & $\begin{array}{l}\text { Bark } \\
\text { Extract Of } \\
\text { Nothapod } \\
\text { ytes } \\
\text { Nimmonia } \\
\text { na } \\
\text { (J. } \\
\text { Graham) }\end{array}$ & $\begin{array}{l}\text { Cardiac } \\
\text { Glycosides } \\
\text { (Cardenolid } \\
\text { es), } \\
\text { Glycosides }\end{array}$ & $\begin{array}{l}\text { UV, FTIR, } \\
\text { HPLC }\end{array}$ & $\begin{array}{l}\text { UV ,FTIR ,HPLC with PDA detector used to } \\
\text { detect Cardiac Glycosides } \\
\text { (Cardenolides), Glycosides, by Anita Patil. }\end{array}$ & $\begin{array}{l}\text { [Anita Patil } \\
\text { etal 2014] }\end{array}$ \\
\hline 10. & $\begin{array}{l}\text { Indian } \\
\text { Seawood }\end{array}$ & $\begin{array}{l}\text { Anthraquino } \\
\text { ne } \\
\text { glycosides }\end{array}$ & $\begin{array}{l}\text { UV-Vis, FT- } \\
\text { IR }\end{array}$ & $\begin{array}{l}\text { UV, FTIR techniques are used for detection } \\
\text { and identification of } \\
\text { Anthraquinone glycosides by D.R.Chejara. }\end{array}$ & $\begin{array}{l}\text { [D.R.Chejara } \\
\text { etal 2014] }\end{array}$ \\
\hline
\end{tabular}

\subsection{Hyphenated techniques for Glycosides:}

2.1.1 Quercus leaf teas: A complete characterization of the phenolic profile of leaves infusions from seven Mexican Quercus species was developed by Rocio Garcia Villalba using different LC-DAD-MS/MS methodologies. The main families of phenolic compounds identified and quantified were; hydrolysable tannins and flavanol glycosides, based on their fragmentation patterns and UV spectra, proanthocyanidins analyzed after acid-catalysis in the presence of phloroglucinol, and phenolic acids evaluated using UPLC-triple quadrapole mass spectrometer(QqQ) ${ }^{[4]}$.

2.1.2 Digitalis purpurea (Foxglove) plant: Digitoxin and digoxin -cardiac glycosides are identified by LC/MS/MS method by Xiaoning Lu, David S. Bell. Digitoxin and digitalin square measure viscus glycosides derived from the Foxglove plant. They have been in use for centuries for treatment of various heart conditions. Because of their narrow therapeutic range and high toxicity, their levels in patients taking digitoxin or digoxin are monitored $^{[5]}$.

2.1.3 Bauhinia forficata is used in folk medicine for its hypoglycemiant effect. In the south of Brazil, the race pruinosa is found in an exceedingly region with the characteristic flora, pampa community. This species has been consumed by the local population as a tea for diabetes treatment. Lidiane da Silveira Farias studied the chemical composition of hydroethanolic extracts using LC/ESI-MS. The leaf extracts were prepared by percolation with $50 \% \quad(\mathrm{v} / \mathrm{v})$ ethanol. The chromatographic analyses were performed using a reverse-phase system, gradient elution with acetonitrile:phosphoric acid $0.05 \%$, and ESI-MS in the positive ion mode. The chemical profile of the 
flavonoids was suggested to involve four quercetin and kaempferol glycosides ${ }^{[6]}$.

2.1.4 Cynodon dactylon sp. : The Cynodon dactylon sp. occupies its unique place in the traditions, religions and cultures of different societies. In the present study, Phytochemical screening of methanolic, petroleum ether, ethanolic and aqueous extracts of Cynodon dactylon revealed the presence of 17 different phytoconstituents. HPLC , LC-MS , H1-NMR , FTIR analysis for the presence of Glycosides done by Zabin k. bagewadi [7]

2.1.5 Pergularia daemia (Forssk) Chiov : Gas Chromatography - Mass Spectrum (GCMS) analysis done for screening of phytochemicals and to identify 1,2-Benzenedicarboxylic acid, diethyl ester (CAS) Synaptogenin B by Rukshana MS, Doss A ${ }^{[8]}$.

2.1.6 leaves of Sauropus Androgynus : In the GCMS analysis shows the presence of Cardenolides bioactive compounds analysed by Senthamarai Selvi. ${ }^{[9]}$.

\subsection{Alkaloids:}

2.1.7 Moringa peregrina (Forssk.) Fiori leaves : All the prepared extracts were also analyzed by gas chromatography-mass spectrometry to identify and characterize polyphenols (tannins and flavonoids), steroids, alkaloid, carbohydrate glycosides, cardiac glycosides, and terpenoids by Mooza Al-Owaisi [10].

2.1.8 Leaves Of Albizia Lebbeck Benth : FTIR method was performed on a Thermo Scientific Spectrophotometer system which was used to detect Tri-O-Glycoside Flavonols Kaempferol And Quercetin by MD. Nazneen Bobby ${ }^{[11]}$.

2.1.9 Bark Extract Of Nothapodytes Nimmoniana (J. Graham) : UV ,FTIR ,HPLC with PDA detector used to detect Cardiac Glycosides (Cardenolides), Glycosides, by Anita Patil ${ }^{[12]}$.

2.2 Indian Seawood : UV, FTIR techniques are used for detection and identification of Anthraquinone glycosides by D.R.Chejara ${ }^{[13]}$.

Table: 2 Hyphenated techniques for Alkaloids

\begin{tabular}{|c|c|c|c|c|c|}
\hline $\begin{array}{l}\text { Sr. } \\
\text { No }\end{array}$ & $\begin{array}{l}\text { Name of } \\
\text { Plant }\end{array}$ & $\begin{array}{c}\text { Name of active } \\
\text { constituent }\end{array}$ & $\begin{array}{c}\text { Hyphenated } \\
\text { technique } \\
\text { used }\end{array}$ & Significance & Reference \\
\hline 1. & $\begin{array}{l}\text { Rhodolirium } \\
\text { andicola }\end{array}$ & $\begin{array}{l}\text { Galanthamine-type } \\
\text { alkaloids such as } \\
\text { lycoramine, } \\
\text { galanthaminonand } \\
\text { acetyl-1,2-dihidro- } \\
\text { galanthamine, } \\
\text { galanthamine } \\
\text { haemanthamine (B, C) } \\
\text { and tazettine(D) }\end{array}$ & GC-MS & $\begin{array}{l}\text { 12alkaloids like } \\
\text { Galanthamine-type } \\
\text { alkaloids such } \\
\text { lycoramine, } \\
\text { galanthaminonand } \\
\text { acetyl-1,2-dihidro- } \\
\text { galanthamine, } \\
\text { galanthamine } \\
\text { haemanthamine (B, C) and } \\
\text { tazettine(D were detected } \\
\text { and identified using gas } \\
\text { chromatography-mass } \\
\text { spectrometry by Felipe } \\
\text { Moraga-Nicolas. }\end{array}$ & $\begin{array}{l}\text { [Felipe } \\
\text { Moraga- } \\
\text { Nicolás } \\
\text { etal 2017] }\end{array}$ \\
\hline 2. & $\begin{array}{l}\text { Harrisia } \\
\text { adscendens }\end{array}$ & $\beta$-carboline alkaloid & FT-NMR & $\begin{array}{l}\text { The qualitative phyto- } \\
\text { chemical and FT-NMR } \\
\text { analysis of the extract } \\
\text { showed the presence of } \beta \text { - } \\
\text { carboline alkaloid } \\
\text { alkaloids by George Luís } \\
\text { Dias dos Santos. }\end{array}$ & $\begin{array}{l}\text { [George } \\
\text { Luís Dias } \\
\text { dos Santos } \\
\text { etal 2017] }\end{array}$ \\
\hline
\end{tabular}




\begin{tabular}{|c|c|c|c|c|c|}
\hline 3. & $\begin{array}{l}\text { Eucalyptus } \\
\text { globules } \\
\text { Labill. }\end{array}$ & $\begin{array}{l}\text { alpha-farnesene, } \\
\text { sesquiterpene. }\end{array}$ & $\begin{array}{l}\text { GC-MS, } \\
\text { NMR,IR }\end{array}$ & $\begin{array}{l}\text { Investigation of alpha- } \\
\text { farnesene, a sesquiterpene } \\
\text { done using IR, GC-MS and } \\
\text { NMR by Kalpesh B. } \\
\text { Ishnava. }\end{array}$ & $\begin{array}{l}\text { [Kalpesh } \\
\text { B. Ishnava } \\
\text { etal 2012] }\end{array}$ \\
\hline 4. & Punica species & $\begin{array}{l}\text { Propanoic acid, } \\
\text { benzenedicarboxylic acid, } \\
\text { methoxypropionic acid } \\
\text { and methyl amine }\end{array}$ & GC-MS & $\begin{array}{l}\text { Propanoic acid, } \\
\text { benzenedicarboxylic } \\
\text { acid,methoxypropionic } \\
\text { acid and methyl amine } \\
\text { detected and analysed by } \\
\text { GC-MS analysis by Asma } \\
\text { A. Al-Huqail. }\end{array}$ & $\begin{array}{l}\text { [Asma A. } \\
\text { Al-Huqail } \\
\text { etal 2015] }\end{array}$ \\
\hline 5. & $\begin{array}{l}\text { Sceletium } \\
\text { tortuosum }\end{array}$ & $\begin{array}{l}\text { Mesembrine-type } \\
\text { alkaloids (mesembrenol, } \\
\text { mesembranol, } \\
\text { mesembrenone and } \\
\text { mesembrine) }\end{array}$ & $\begin{array}{l}\text { RP-UHPLC } \\
\text { PDA, GC- } \\
\text { MS }\end{array}$ & $\begin{array}{l}\text { Mesembrine-type alkaloids } \\
\text { in } \\
\text { S. tortuosum identified } \\
\text { using RP-UHPLC } \\
\text { PDA, GC-MS techniques } \\
\text { by E.A. Shikanga. }\end{array}$ & $\begin{array}{l}\text { [E.A. } \\
\text { Shikanga } \\
\text { etal 2012] }\end{array}$ \\
\hline 6. & $\begin{array}{l}\text { Galanthus } \\
\text { cilicicus }\end{array}$ & $\begin{array}{l}\text { Alkaloids tazettine } \\
\text { galanthamine , sanguinine } \\
\text {, and haemanthamine. }\end{array}$ & GC/MS & $\begin{array}{l}\text { Using GC/MS technique } \\
\text { alkaloids tazettine } \\
\text { galanthamine, sanguinine, } \\
\text { and haemanthamine } \\
\text { identified by G.I. Kaya. }\end{array}$ & $\begin{array}{l}\text { [G.I. Kaya } \\
\text { etal 2016] }\end{array}$ \\
\hline 7. & $\begin{array}{l}\text { Phaleria } \\
\text { macrocarpa }\end{array}$ & a-glucosidase & $\begin{array}{l}\text { FTIR, FTIR } \\
\text { spectroscopy- } \\
\text { based } \\
\text { fingerprinting. }\end{array}$ & $\begin{array}{l}\text { The characterization of a- } \\
\text { glucosidase done by using } \\
\text { Fourier transform infrared } \\
\text { spectroscopy (FTIR)-by } \\
\text { Sabina Easmin. }\end{array}$ & $\begin{array}{l}\text { [Sabina } \\
\text { Easmin } \\
\text { etal 2016] }\end{array}$ \\
\hline 8. & $\begin{array}{l}\text { Leucetta } \\
\text { chagosensis } \\
\text { Sponge }\end{array}$ & $\begin{array}{l}\text { methyldorimidazole, } \\
\text { preclathridine, } \\
\text { naamine and leucettamine }\end{array}$ & 1H NMR, MS & $\begin{array}{l}\text { The isolation } \\
\text { methyldorimidazole, } \\
\text { preclathridine, naamine } \\
\text { and leucettamine were } \\
\text { elucidated by employing } \\
\text { spectroscopic techniques } \\
\text { (1H NMR, MS and UV) } \\
\text { by Wafaa H.B. Hassan. }\end{array}$ & $\begin{array}{l}\text { [Wafaa } \\
\text { H.B. } \\
\text { Hassan } \\
\text { etal 2009] }\end{array}$ \\
\hline 9. & $\begin{array}{l}\text { Cyperus } \\
\text { rotundus L }\end{array}$ & $\begin{array}{l}\text { alkaloids, phenols, } \\
\text { flavonoids, and terpenes }\end{array}$ & GC-MS & $\begin{array}{l}\text { The rhizomes showed the } \\
\text { presence of alkaloids, } \\
\text { phenols, flavonoids, } \\
\text { Terpenes. Purified } \\
\text { secondary metabolites } \\
\text { compound, alkaloids, and } \\
\text { phenols were extracted } \\
\text { from rhizomes using GC- } \\
\text { MS analysis by Russell } \\
\text { A.Abo-Altemen. }\end{array}$ & $\begin{array}{l}\text { [Russell } \\
\text { A.Abo- } \\
\text { Altemen } \\
\text { etal 2018] }\end{array}$ \\
\hline 10. & $\begin{array}{l}\text { Crinum } \\
\text { erubescens } \\
\text { Aiton }\end{array}$ & $\begin{array}{l}\text { 1- } \\
\text { epidemethylbowdensine, }\end{array}$ & GC-MS & $\begin{array}{l}\text { The alkaloid 1- } \\
\text { epidemethylbowdensine, } \\
\text { detected by } \\
\text { means of GC-MS by } \\
\text { Caroline Gastaldi Guerrieri }\end{array}$ & $\begin{array}{l}\text { [Caroline } \\
\text { Gastaldi } \\
\text { Guerrieri } \\
\text { etal 2015] }\end{array}$ \\
\hline
\end{tabular}


2.3.1 Rhodolirium andicola : 12alkaloids like Galanthamine-type alkaloids such as lycoramine, galanthaminonand 3-O-acetyl-1,2-dihidrogalanthamine, galanthamine $(\mathrm{A})$, haemanthamine $(\mathrm{B}, \mathrm{C})$ and tazettine( $\mathrm{D}$ were detected and identified using gas chromatography-mass spectrometry by Felipe Moraga-Nicolas ${ }^{[14]}$.

2.3.2 Harrisia adscendens : The secondary metabolites obtained from the vegetal drug by chromatographic andspectroscopic techniques and to evaluate the antimicrobial activity of the extract. The qualitative phyto-chemical analysis of the extract showed suggestive results for the presence of $\beta$-carboline alkaloids ${ }^{[15]}$.

2.3.3 Eucalyptus globules Labill : Investigation on the structure elucidation of the bioactive compound using IR, GC-MS and NMR techniques revealed the presence of alpha-farnesene, a sesquiterpene $^{[16]}$.

2.3.4 Punica species : Species of Punica (Punica granatum and Punica protopunica) were subjected to GC-MS analysis. Twenty-one and 14 compounds were identified in $\mathrm{P}$. granatum and $\mathrm{P}$. protopunica peel seeds, respectively. Propanoic acid, benzenedicarboxylic acid,methoxypropionic acid and methyl amine detected and analysed by GC-MS analysis ${ }^{[17]}$.

2.3.5 Sceletium tortuosum: Reversed section radial performance LC with photodiode array detector (RP-UHPLC PDA) and GC coupled to mass spectroscopic analysis (GC-MS) strategies for quantitative assessment of mesembrine-type alkaloids in $\mathrm{S}$. tortuosum raw materials and products ${ }^{[18]}$.

2.3.6 Galanthus cilicicus: The alkaloid patterns of bulbs and aerial parts of G. cilicicus were conjointly studied by gas chromatography/mass spectroscopic analysis (GC/MS). Twenty alkaloids were detected. In the aerial elements, among the detected alkaloids, haemanthamine and tazettine were the main alkaloids, whereas in the bulbs galanthamine and tazettine were predominantly found ${ }^{[19]}$.

2.3.7 Phaleria macrocarpa : The characterization of a-glucosidase inhibitory activity of $P$. macrocarpa extracts done by FTIR-based metabolomics. P. macrocarpa extracts mistreatment Fourier rework infrared spectroscopic analysis (FTIR)-based metabolomics. P. macrocarpa and its extracts contain thousands of compounds having synergistic effect ${ }^{[20]}$.

2.3.8 Leucetta chagosensis sponge : The isolation of 2 new alkali alkaloids, methyldorimidazole, preclathridine along with the known compounds naamine and leucettamine. The structures of the newly compounds were elucidated by employing spectroscopic techniques (1H NMR, MS and UV). The structures of the known compounds 3 and 4 were determined by comparison of their $1 \mathrm{H}$ NMR and Mass spectroscopic data ${ }^{[21]}$.

2.3.9 Cyperus rotundus $L$ : The rhizomes showed the presence of alkaloids, phenols, flavonoids, Terpenes. Purified secondary metabolites compound, alkaloids, and phenols were extracted from rhizomes of Cyperus rotundus L. GC-MS analysis of methyl alcohol extract showed 10 compounds belong to alkaloids extract throughout retention time twenty four $\mathrm{min}$ and twenty-five compounds belong to phenol extract throughout retention time twenty five minute were identified [22].

2.4. Crinum erubescens Aiton : The compound 1epidemethylbowdensine, detected by means that of GC-MS as part of a worldwide Amaryllidaceae family. Phytochemical Program, is rumored for the primary time and fully characterised by physical and spectroscopic methods ${ }^{[23]}$.

\subsection{Tannins:}

Table: 3 Hyphenated techniques for Tannins

\begin{tabular}{|l|l|l|l|l|l|}
\hline $\begin{array}{l}\text { Sl. } \\
\text { No }\end{array}$ & Name of Plant & $\begin{array}{l}\text { Name of active } \\
\text { constituent }\end{array}$ & $\begin{array}{l}\text { Hyphenated } \\
\text { technique used }\end{array}$ & Significance & Reference \\
\hline 1. & $\begin{array}{l}\text { Periandra } \\
\text { dulcis roots }\end{array}$ & $\begin{array}{l}\text { Hydrolysable tannins, } \\
\text { such as } \\
\text { dihexahydroxydiphenoyl } \\
\text { galloyl glucoside and } \\
\text { trisgalloyl } \\
\text { hexahydroxydiphenoyl }\end{array}$ & $\begin{array}{l}\text { HPL-ESI- } \\
\text { MS/MS }\end{array}$ & $\begin{array}{l}\text { An HPL-ESI- } \\
\text { MS/MS system was } \\
\text { employed to detect }\end{array}$ & $\begin{array}{l}\text { [Giuseppina } \\
\text { Negri } \\
\text { tannins etal } \\
\text { Giuseppina Negri. by }\end{array}$ \\
\end{tabular}




\begin{tabular}{|c|c|c|c|c|c|}
\hline & & glucose & & & \\
\hline 2. & $\begin{array}{l}\text { Clusia } \\
\text { lanceolata }\end{array}$ & $\begin{array}{l}\text { The major components } \\
\text { of both galled and non- } \\
\text { galled leave oils were } \beta \text { - } \\
\text { caryophyllene ( } 51.62 \% \\
\text { and } 57.16 \%) \text {, } \\
\beta \text {-caryophyllene }(8.42 \% \\
\text { and } 8.94 \%) \text {, germacrene } \\
D(4.33 \% \text { and } 6.91 \%) \text {, } \\
\text { biciclogermacrene } \\
(2.58 \% \text { and } 2.94 \%) \text { and } \\
\text { viridiflorene }(2.46 \% \text { and } \\
2.09 \%) \text {. }\end{array}$ & $\begin{array}{l}\text { GC } \\
\text { GC/MS. }\end{array}$ & $\begin{array}{l}\text { galled and non-galled } \\
\text { leave oils like } \beta- \\
\text { caryophyllene were } \\
\text { obtained by GC and } \\
\text { GC/MS by Rafaela } \mathrm{O} \text {. } \\
\text { Ferreira. }\end{array}$ & $\begin{array}{lr}{[\text { Rafaela }} & \text { O. } \\
\text { Ferreira } & \text { etal } \\
2014] & \end{array}$ \\
\hline 3. & $\begin{array}{l}\text { Campomanesia } \\
\text { adamantium }\end{array}$ & $\begin{array}{l}\text { Aromadendrene, } \\
\text { humulene,allo- } \\
\text { aromadendrene, } \\
\text { eudesma-4,11-diene } \\
\text { spathulenol, cubenol. }\end{array}$ & $\begin{array}{l}\text { HPLC, } \\
\text { 13CNMR }\end{array}$ & $\begin{array}{l}\text { HPLC was used to } \\
\text { evaluate the purified } \\
\text { compounds, and } \\
\text { then, } 1 \mathrm{H} \text { and13CNMR } \\
\text { analysis } \\
\text { performed } \\
\text { elucidate } \\
\text { molecular structures } \\
\text { by Stone Sá, Luíza T. } \\
\text { Chaul. }\end{array}$ & $\begin{array}{l}\text { Stone Sá, Luíza } \\
\text { T. Chaul, etal } \\
2017\end{array}$ \\
\hline 4. & Canna indica $\mathrm{L}$ & $\begin{array}{l}\text { 3' hydroxytrimethoprim, } \\
\text { 3,7-epoxycaryophyllan- } \\
6 \text {-one, swietenine, } \\
\text { typhasterol, } \\
\text { hexacosanedioic acid } \\
\text { and } 3 \beta, \quad 6 \alpha, 7 \alpha- \\
\text { trihydroxy-5 } 3 \text { - } \\
\text { cholan-24-oic acid }\end{array}$ & $\begin{array}{l}\text { H1-NMR and } \\
\text { HR-LC/MS-MS }\end{array}$ & $\begin{array}{l}\text { Phytochemical } \\
\text { evaluation } \\
\text { done by H1-NMR } \\
\text { and HR-LC/MS-MS } \\
\text { analysis by Subhash } \\
\text { T. Kumbhar. }\end{array}$ & $\begin{array}{l}\text { [Subhash } \\
\text { Kumbhar, etal } \\
\text { 2018] }\end{array}$ \\
\hline 5. & $\begin{array}{l}\text { Grape pomace } \\
\text { seed }\end{array}$ & $\begin{array}{l}\text { Several galloylated and } \\
\text { non-galloylated flavan- } \\
\text { 3-ol compounds, } \\
\text { catechin with } \\
\text { acetaldehyde. }\end{array}$ & $\begin{array}{l}\text { HPLC/ } \\
\text { DAD-MSn, } \\
\text { LC-ESI- } \\
\text { FTICR-MS }\end{array}$ & $\begin{array}{l}\text { HPLC/ } \\
\text { DAD-MSn, LC-ESI- } \\
\text { FTICR-MS showed } \\
\text { the presence of } \\
\text { several galloylated } \\
\text { and non-galloylated } \\
\text { flavan-3-ol } \\
\text { compounds studied } \\
\text { by Ismael Ivan } \\
\text { Rockenbach. }\end{array}$ & $\begin{array}{l}\text { [Ismael Ivan } \\
\text { Rockenbach } \\
\text { etal 2012] }\end{array}$ \\
\hline
\end{tabular}

2.5.1 Periandra dulcis roots: An HPLC-ESIMS/MS system was employed to provide a rapid method to make a tentative characterization of the compounds like Hydrolysable tannins, such as dihexahydroxydiphenoyl galloyl glucoside and trisgalloyl hexahydroxydiphenoyl glucose found in the hydroethanolic extract from P. dulcis roots ${ }^{[24]}$.

2.5.2 Clusia lanceolata: Clusiaceae, were obtained by hydrodistillation and analyzed by $\mathrm{GC}$ and GC/MS. The chemical composition of both oils was similar, with a predominance of sesquiterpene caryophyllenes ${ }^{[25]}$.

2.5.3 Campomanesia adamantium : HPLC was used to evaluate the purified compounds like Aromadendrene, $\alpha$-humulene,allo-aromadendrene, cis-eudesma-4,11-diene spathulenol, cubenol, and then, $1 \mathrm{H}$ and13CNMR analysis was performed to elucidate the molecular structures ${ }^{[26]}$. 
2.5.4 Canna indica L: Phytochemical evaluation of hydroalcoholic extract (HAE) of C. indica L. roots and rhizomes; including preliminary screening of 3'-hydroxytrimethoprim, 3,7epoxycaryophyllan-6-one, swietenine, typhasterol, hexacosanedioic acid and $3 \beta, 6 \alpha, 7 \alpha-$-trihydroxy- $5 \beta$ cholan-24-oic acid by thin layer chromatography, H1-NMR and HR-LC/MS-MS analysis ${ }^{[27]}$.

2.5.5 Grape pomace seed: High-performance liquid chromatography coupled with a diode array detector and an ion trap mass spectrometer (HPLC/ DAD-MSn) showed the presence of several galloylated and non-galloylated flavan-3-ol compounds and the presence of condensed products of catechin with acetaldehyde. Fouriertransform ion cyclotron resonance mass spectrometry (LC-ESI-FTICR-MS) enabled the assignment of elemental compositions to 251 different flavan-3-ol compounds in Cabernet Sauvignon variety, including isomers of 28 different molecular classes ${ }^{[28]}$.

\subsection{Resins:}

Table: 4 Hyphenated techniques for Resins

\begin{tabular}{|c|c|c|c|c|c|}
\hline $\begin{array}{l}\text { Sr. } \\
\text { No }\end{array}$ & $\begin{array}{l}\text { Name of } \\
\text { Plant }\end{array}$ & $\begin{array}{l}\text { Name of active } \\
\text { constituent }\end{array}$ & $\begin{array}{l}\text { Hyphenated } \\
\text { technique used }\end{array}$ & Significance & Reference \\
\hline 1. & Alkyd resin & $\begin{array}{l}\text { styrenated alkyds } \\
\text { and } \\
\text { palm kernel oil- } \\
\text { modified alkyds }\end{array}$ & FTIR, GC-MS & $\begin{array}{l}\text { The styrenated alkyds } \\
\text { and palm kernel oil } \\
\text { modified alkyds were } \\
\text { all characterized using } \\
\text { Fourier Transform } \\
\text { Infrared (FTIR) and } \\
\text { GC-MS instrumental } \\
\text { technique by Uzoh } \\
\text { C.F. }\end{array}$ & $\begin{array}{l}\text { [Uzoh C.F. etal, } \\
\text { 2015] }\end{array}$ \\
\hline 2. & Myrrh resin & $\begin{array}{l}\text { Calcium, } \\
\text { magnesium, } \\
\text { aluminum, } \\
\text { phosphorus, } \\
\text { chlorine, chromium, } \\
\text { bromine and } \\
\text { scandium, } \\
\text { limonene, } \\
\text { curzerene, } \\
\text { germacrene } \\
\text { isocericenine, B, } \\
\text { myrcenol, } \\
\text { beta selinene, and } \\
\text { spathulenol }\end{array}$ & $\begin{array}{l}\text { GC-MS } \\
\text { ICP-MS }\end{array}$ & $\begin{array}{l}\text { The organic and } \\
\text { inorganic composition } \\
\text { of the } \\
\text { myrrh gum resin has } \\
\text { been investigated GC- } \\
\text { MS and inductively } \\
\text { coupled plasma-mass } \\
\text { spectrometry (ICP-MS) } \\
\text { executed by Syed } \\
\text { Rizwan Ahamad. }\end{array}$ & $\begin{array}{lr}\text { [Syed } & \text { Rizwan } \\
\text { Ahamad } & \text { etal } \\
2016] & \end{array}$ \\
\hline 3. & $\begin{array}{l}\text { Taenia } \\
\text { saginata } \\
\text { metacestode }\end{array}$ & $\begin{array}{l}\text { carboxymethyl } \\
\text { sepharose (CM) and } \\
\text { diethylaminoethyl } \\
\text { sepharose (DEAE) } \\
\text { resins }\end{array}$ & $\begin{array}{l}\text { Ion-exchange } \\
\text { chromatography }\end{array}$ & $\begin{array}{l}\text { carboxymethyl } \\
\text { sepharose (CM) and } \\
\text { diethylaminoethyl } \\
\text { sepharose (DEAE) } \\
\text { resins analysed using } \\
\text { Ion-exchange } \\
\text { chromatography by } \\
\text { Daniela da Silva } \\
\text { Nunes. }\end{array}$ & $\begin{array}{l}\text { [Daniela da } \\
\text { Silva Nunes, etal } \\
\text { 2012] }\end{array}$ \\
\hline 4. & $\begin{array}{l}\text { fossil resins } \\
\text { from the } \\
\text { Czech } \\
\text { Republic }\end{array}$ & $\begin{array}{l}\text { organic macerals, } \\
\text { Czech resins }\end{array}$ & GC/MS & $\begin{array}{l}\text { The extracts were } \\
\text { analysed using GC/MS } \\
\text { by Martina Havelcová. }\end{array}$ & $\begin{array}{l}\text { [Martina } \\
\text { Havelcová etal } \\
\text { 2014] }\end{array}$ \\
\hline
\end{tabular}




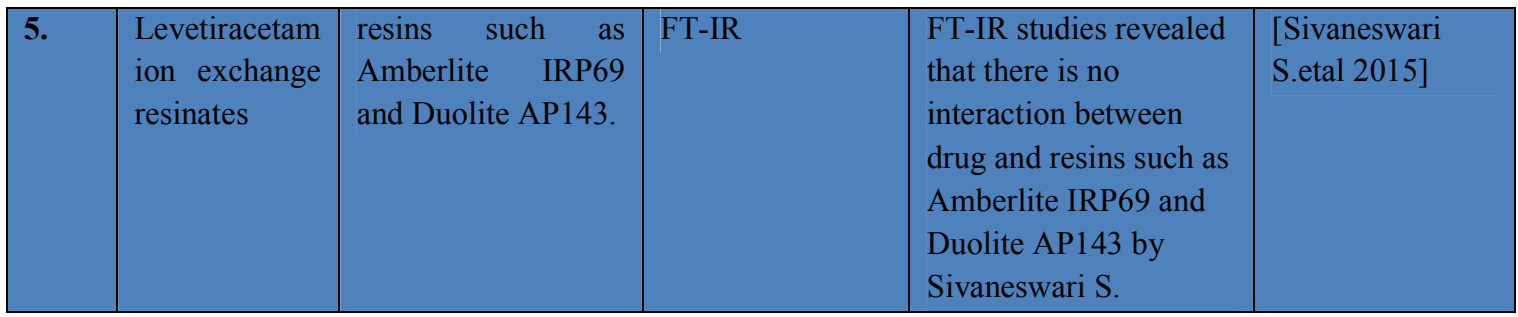

2.6.1 Alkyd resin: The styrenated alkyds and nut oil-modified alkyds were all characterised for analysis of physico-chemical properties. Structural elucidation of the raw materials and their copolymers was done with Fourier Transform Infrared (FTIR) and GC-MS instrumental technique ${ }^{[29]}$.

2.6.2 Myrrh resin: The organic and inorganic composition of the myrrh gum resin like Calcium, magnesium, aluminum, phosphorus, chlorine, chromium, bromine and scandium, limonene, curzerene, germacrene $\mathrm{B}$, isocericenine, myrcenol, beta selinene, and spathulenol has been investigated using gas chromatography-mass spectrometry (GC-MS) and inductively coupled plasma-mass spectrometry (ICP-MS). Analysis executed by ICP-MS reveals the presence of various inorganic elements in significant amount in the myrrh resin ${ }^{[30]}$.

2.6.3 Taenia saginata metacestode: Ion-exchange procedure for identification and detection of carboxymethyl sepharose (CM) and diethylaminoethyl sepharose (DEAE) resins, as a source of antigenic markers applicable in the immunodiagnosis of neurocysticercosis (NCC) ${ }^{[31]}$.

2.6.4 Fossil resins from the Czech Republic: The samples were sonicated with dichloromethane and the extracts were analysed for presence of organic macerals, Czech resins without derivatisation by GC/MS using a Trace Ultra - DSQ II instrument equipped with a capillary column with a fixed stationary phase TR-5MS ${ }^{[32]}$.

2.6.5 Levetiracetam ion exchange resinates: FTIR studies revealed that there is no interaction between drug and resins such as Amberlite IRP69 and Duolite AP143..The DSC and XRD studies proved that the drug is in amorphous nature. Using the same concentration of resins, Xanthan gum as suspending agent in a liquid dosage form for pediatric use was formulated ${ }^{[33]}$.

\section{CONCLUSION:}

The technique developed from the coupling of a separation technique and an on-line spectroscopic detection technology is known as hyphenated technique. The remarkable improvement in hyphenated analytical method over the last two decades has significantly broadened their application in the analysis of Plant metabolites. In this study we wants to conclude this the various active constituents and plant metabolites like Glycosides, Alkaloids, Tannins , and Resins can be easily identified \& detected by using Double and Triple Hyponated techniques.

\section{DISCUSSION:}

Hyponated techniques are usefl for fast and accurate analysis. It provides, higher degree of automation as well as higher sample throughput. Hyponated techniques are also useful for better reproducibility. It also establishes the reduction of contamination due to its closed system and also separation of quantification at the same time.

\section{REFERENCES :}

1. Nagajyothi S, Swetha Y, Neeharika J, Suresh PV, Ramarao N., Hyphenated Techniques- A Comprehensive Review ., International Journal of Advance Research and Development 2017; 2(4): 1-9.

2. Devi T, Tulja GR, Patlolla P., A Review on Hyphenated Separation Techniques Used in Pharmaceutical Analysis., IOSR Journal of Pharmacy and Biological Sciences,2016; 11(6): $65-74$

3. Chinchole R, Hatre PM, Desai U, Chavan R., Recent Applications Of Hyphenated Liquid Chromatography Techniques In Forensic Toxicology: A Review., Int. J. Pharm. Sci. Rev. Res. 2012; 14(1):12, 57-63.

4. Rocio GV., Comprehensive characterization by LC-DAD-MS/MS of the phenoplast 
composition of seven Quercus leaf teas. Elsevier,2017; 63: 38-46.

5. Xiaoning L, Bell DS., Rapid, Sensitive, and Quantitative LC/MS/MS Determination of Digitoxin and Digoxin in Plasma., Reporter US Volume 2010; 33.3:7-12.

6. Farias LS, Andreas SL., LC/ESI-MS Method Applied To Characterization of Flavonoids Glycosides in B. forficata subsp., Pruinosa, Quím. Nova 2014; 37: 472-585.

7. Bagewadi ZK, Siddanagouda RS, Baligar PG., Phytoconstituents investigation by Lc-Ms and evaluation of Anti-Microbial And Anti-Pyretic properties of Cynodon Dactylon., International Journal of Pharmaceutical Sciences And Research 2014; 5(7): 2874-2889.

8. Rukshana MS, Doss A , Rani KP., Phytochemical Screening and GC-MS Analysis of Leaf Extract of Pergularia daemia (Forssk) Chiov., Asian Journal of Plant Science and Research 2017; 7(1): 9-15

9. Selvi S, Basker A., Phytochemical Analysis and GC-MS identification within the leaves of Sauropus Androgynus., International Journal of Drug Development \& Research 2012; 4(1): 0975-9344

10. Al-Owaisi M, Al-Hadiwi N, Khan SA., GCMS analysis, determination of total phenolics, flavonoid content and free radical scavenging activities of various crude extracts of Moringa peregrina (Forssk.) Fiori leaves., Asian Pac J Trop Biomed 2014; 4(12): 964-970.

11. Bobby N, Wesely J., Ft-Ir Studies On The Leaves Of Albizia Lebbeck Benth., International Journal of Pharmacy and Pharmaceutical Sciences 2012; 4(3): 09751491.

12. Patil A, Patil S, Mahure S, Kale A., UV, FTIR, HPLC Confirmation of Camptothecin an Anticancer Metabolite from Bark Extract of Nothapodytes nimmoniana (J. Graham)., American Journal of Ethnomedicine 2014; 1(3): 174-185.

13. Chejara DR, Kondaveeti S, Ramavatar M, Siddhanta AK., Antioxident activity and phytochemical analysis of a few Indian seaweed species., Indian Journal of GeoMarine Sciences 2014;43 (A): 507-518.

14. Felipe M, Jara C, Ricardo G, Patricio I, Herbert V, Quirozb A, Becerrad J, Mutisb A, Hormazábalb E,Rhodolirium A, etal., A new renewable source of alkaloids with acetylcholinesterase inhibitory activity, a study from nature to molecular docking., Revista Brasileira de Farmacognosia 2018; 28: $34-43$.

15. Santosa GL, Emerson LL, Fernandesa AF, Rochaa WR, Cataoa RM, Filhob RB, Tavaresc JF, Fechinea IM, Harley A, etal., Phytochemical study of Harrisia adscendens., Revista Brasileira de Farmacognosia 2018; 28: 298-302.

16. Ishnava KB, Chauhan JB, Bara MB., Anticariogenic and phytochemical evaluation of Eucalyptus globules Labill., Saudi Journal of Biological Sciences 2013; 20: 69-74.

17. Al-Huqail AA, Elgaaly GA, Ibrahim MM., Identification of bioactive phytochemical from 2 Punica species using GC-MS and estimation of antioxidant activity of seed extracts., Saudi Journal of Biological Sciences 2018; 25: 1420-1428.

18. Shikanga EA, Kamatou GPP, Chen W, Combrinck S, Viljoen AM., Validated RPUHPLC PDA and GC-MS methods for the analysis of psychoactive alkaloids in Sceletium tortuosum., South African Journal of Botany 2012; 82: 99-107.

19. Kaya GI , Uzun K, Bozkurt B, Onur MA, Somer NU, Glatzel DK, Furst R., Chemical characterization and biological activity of an endemic Amaryllidaceae species: Galanthus cilicicus., South African Journal of Botany 2017; 108: 256-260.

20. Easmin S, Sarker Md. ZI, Ghafoor K, Ferdosh S, Jaffri J, Ali Md. E, Mirhosseini H, Al-Juhaimi FY, Perumal V, Khatib A,etal., Rapid investigation of a-glucosidase inhibitory activity of Phaleria macrocarpa extracts using FTIR-ATR based fingerprinting., Journal of food and drug analysis 2017; 25: $306-315$.

21. Hassan W, Al-Taweel AM, Proksch P., Two new imidazole alkaloids from Leucetta chagosensis sponge., Saudi Pharmaceutical Journal 2009; 17: 295- 298.

22. Russell A, Altemen A, Al-Shammari AM,.Shawkat MS., GC-MS analysis and chemical composition identification of Cyperus royundus L., Iraq. Energy Procedia $2019 ; 157: 1462-1474$. 
23. Guerrieri CG, Pigni NB, Andrade JP, Santos VD, Binns F, Borges WS, Viladomat F, Bastida J, etal., Alkaloids from Crinum erubescens Aiton., Arabian Journal of Chemistry 2016; 9 : 688-693.

24. Negri G, Tabach R., Saponins, tannins and flavonols found in hydroethanolic extract from Periandra dulcis roots., Rev Bras Farmacogn 2013; 23:851-860.

25. Ferreira RO, Carvalho AR, Silva TM, Castro RN, Silva TM, Carvalho MG, etal., Distribution of metabolites in galled and nongalled leaves of Clusia lanceolata and its antioxidant activity., Rev Bras Farmacogn 2014 ;24: 617-625.

26. Chaula SL, Alvesb VF, Fiuzac TS, Tresvenzola LM, Vazd BG, Ferri PH, Borgese LL, Paulaa JR, etal., Phytochemistry and antimicrobial activity of Campomanesia adamantium Stone., Revista Brasileira de Farmacognosia 2018; 28 :303-311.

27. Kumbhara ST, Patilb SP, Unec HD., Phytochemical analysis of Canna indica L. roots and rhizomes extract., Biochemistry and Biophysics Reports 2018;16:50-55.

28. Rockenbach I, Jungfer E, Ritter C, Schubel BS, Thiele B, Fett R, Galensa R, etal., Characterization of flavan-3-ols in seeds of grape pomace by CE, HPLC-DAD-MSn and LC-ESI-FTICR-MS., Food Research International 2012; $48: 848-855$.

29. Uzoh CF, Obodo NJ, Onukwuli OD.,
Exploring the effect of styrene and anhydride ratio on the coating properties of non-drying vegetable oil based alkyd resin., Journal of King Saud University - Engineering Sciences 2018; 30: 12-21.

30. Ahamad SR, Al-Ghadeer AR, Ali R, Qamar W, Aljarboa S., Analysis of inorganic and organic constituents of myrrh resin by $\mathrm{GC}-$ MS and ICP-MS: An emphasis on medicinal assets., Saudi Pharmaceutical Journal 2017; $25: 788-794$.

31. Nunes DS, Gonzaga HT, Ribeiro VS, Cunha JP, Costa-Cruz JM., Taenia saginata metacestode antigenic fractions obtained by ion-exchange chromatography: Potential source of immunodominant markers applicable in the immunodiagnosis of human neurocysticercosis., Diagnostic Microbiology and Infectious Disease 2013; 76 :36-41.

32. Havelcova M, Sykorova I, Mach K, Dvorak Z., Organic geochemistry of fossil resins from the Czech Republic., Procedia Earth and Planetary Science $2014 ; 10: 303-312$.

33. Sivaneswari S, Karthikeyan E, Veena D, Chandana PJ, Sai Sumana P, Subhashree P, Ramya L, Rajalakshmi R, Ashok Kumar CK, etal., Physiochemical characterization of taste masking levetiracetam ion exchange resinates in the solid state and formulation of stable liquid suspension for pediatric use., Beni suef university journal of basic and applied sciences $2016 ; 5: 126-133$. 